\title{
SISTEM INFORMASI PENERIMAAN SISWA BARU SD CALISA TANJUNG UBAN BERBASIS WEB DAN SMS GATEWAY
}

\author{
${ }^{1}$ Paulina Lubis, ${ }^{2}$ Jajang Nurjaman, ${ }^{3}$ Naufal Muhammad Kautsar \\ 1,2,3 Jurusan Sistem Informasi STT Indonesia Tanjungpinang \\ Jln. Pompa Air No. 28 Tanjungpinang Kepulauan Riau Indonesia \\ lpaulinalubis.pl@gmail.com, ${ }^{2} z a 2 n g 2509 @ g m a i l . c o m,{ }^{3}$ naufalmk@yahoo.com
}

\begin{abstract}
Intisari-Sistem penerimaan siswa baru SD Calisa Tanjung Uban pada saat ini masih menggunakan sistem berbasis desktop dengan menggunakan formulir pendaftaran calon siswa baru. Dengan sistem tersebut, masih terjadi kesalahan dalam input data calon siswa baru dan juga kesulitan dalam menyampaikan hasil PSB secara cepat ke calon siswa baru. Penelitian ini menggunakan model Spiral yang memiliki sifat interaktif yaitu dengan sifat kemungkinan perangkat lunak dikembangkan versinya secara bertahap untuk menghasilkan perangkat lunak yang lengkap dan terkontrol. Penelitian ini meliputi perancangan dan pembangunan Sistem informasi penerimaan siswa baru berbasis Web (PHP dan MySQL) dilengkapi SMS Gateway, serta pengujian kinerja sistem perangkat lunak. Sistem informasi dari penelitian ini diharapkan dapat membantu proses pelaksanaan penerimaan siswa baru.
\end{abstract}

Kata kunci-Sistem Informasi, Penerimaan Siswa Baru, Berbasis Web, SMS Gateway, Spiral

\begin{abstract}
The new student admission system for SD Calisa Tanjung Uban is currently still using a desktop-based system using a new student registration form. With this system, there are still errors in data input for new prospective students and also difficulties in conveying PSB results quickly to prospective new students. This study uses a Spiral model which has an interactive nature, namely the possibility of developing software versions gradually to produce complete and controlled software. This research includes the design and development of a new Web-based admission information system (PHP and MySQL) equipped with an SMS gateway, as well as software system performance testing. The information system from this research is expected to help the process of implementing new student admissions.
\end{abstract}

Keywords - Information Systems, Admission of New Students, Web Based, SMS Gateway, Spiral

\section{PENDAHULUAN}

Proses penyebaran informasi saat ini sangat mudah dan cepat yaitu sejalan dengan perkembangan teknologi informasi. Hampir di segala sendi kehidupan teknologi informasi memegang peranan yang penting. Perkembangan teknologi informasi di Indonesia tidak pernah lepas dari pengaruh globalisasi. Globalisasi terjadi karena adanya proses pertukaran pandangan atau pemikiran mengenai kehidupan yang dipengaruhi oleh faktor teknologi internet, gaya hidup masyarakat, perkembangan telekomunikasi, dan lain-lain.[1].

Penerimaan Peserta Didik Baru (PPDB) merupakan langkah atau proses awal yang dilakukan penyelenggara pendidikan baik tingkat dasar ataupun tinggi. Berdasarkan Peraturan Menteri Pendidikan dan Kebudayaan nomor 44 Tahun 2019, BAB I Pasal 2. Tentang Penerimaan Peserta Didik Baru pada Taman Kanak-Kanak, Sekolah Dasar, Sekolah Menengah Pertama, Sekolah Menengah Atas dan Sekolah Menengah Kejuruan, PPDB dilakukan berdasarkan: a. nondiskriminatif; b. objektif; c. transparan; d. akuntabel; dan e. berkeadilan. (2) Nondiskriminatif sebagaimana dimaksud pada ayat (1) dikecualikan bagi Sekolah yang secara khusus melayani peserta didik dari kelompok gender atau agama tertentu[1]. Sistem Informasi Menurut Hutahaean, "Sistem informasi adalah suatu sistem di dalam suatu organisasi yang mempertemukan kebutuhan pengelolaan transaksi harian, mendukung operasi, bersifat manajerial, dan kegiatan strategi dari suatu organisasi dan menyediakan pihak luar tertentu dengan laporan-laporan yang dibutuhkan".[2]

Dalam melaksanakan kegiatan pendaftaran dan penerimaan siswa baru di suatu sekolah, diperlukan sebuah manajemen yang mengorganisir kegiatan tersebut agar dapat mencapai tujuan. Sistem informasi pendaftaran dan penerimaan siswa yang baik, dapat dijadikan sarana yang penting bagi setiap sekolah dalam meningkatkan mutu dari program pendidikan. Terutama sekolah-sekolah yang memiliki akses pengolahan data yang besar seperti di sekolah SD Calisa Tanjung Uban, karena pengolahan data sudah tidak mungkin lagi menggunakan cara manual karena kurang efektif dan efisien. Sistem manual pendaftaran dan penerimaan siswa baru pada SD Calisa Tanjung Uban yang dimaksud adalah sistem pendaftaran dan pendataan dengan cara 
calon siswa datang ke sekolah kemudian mengambil formulir pendaftaran, yang nantinya setelah formulir tersebut diisi dan melampirkan persyaratan, lalu diserahkan kepada panitia pendaftaran dan nantinya data pendaftaran akan dimasukkan dan diolah menggunakan software /aplikasi pendaftaran siswa baru berbasis dekstop dimana sebenarnya masih ada beberapa kendala yang didapat seperti sulitnya transparasi data pendaftar, kesalahan penginputan data pendaftar, formulir data siswa yang manual dengan menggunakan kertas, menjadikan resiko kehilangan data siswa sangat besar. Dari beberapa kendala yang dihadapi SD Calisa, peneliti bermaksud melakukan pengembangan pada software / aplikasi pendaftaran dan penerimaan siswa baru berbasis dekstop yang digunakan saat ini dengan menerapkan pendaftaran berbasis online dan dengan menambahkan fitur SMS Gateway untuk menyampaikan informasi penerimaan siswa baru secara cepat kepada calon siwa baru. Berdasarkan latar belakang uraian di atas maka penulis tertarik untuk melakukan penelitian di bidang sistem inforamsi berbasis web dengan memilih judul "Sistem Informasi Penerimaan Siswa Baru SD Calisa Tanjung Uban Berbasis Web Dan SMS Gateway".

\section{Metodologi Penelitian}

\section{A. Diagram Konteks}

Diagram konteks adalah diagram yang terdiri dari suatu proses dan menggambarkan ruang lingkup suatu sistem. Diagram konteks merupakan tingkatan tertinggi dalam diagram aliran data dan menggambarkan seluruh input ke sistem atau output dari sistem. Dalam diagram hanya ada satu proses. Proses tersebut diberi nomor nol. Semua entitas eksternal yang ditunjukkan pada diagram konteks berikut aliran data utama menuju dan dari sistem. Diagram tersebut tidak memuat penyimpanan data dan tampak sederhana untuk diciptakan, begitu entitas-entitas eksternal serta aliran data-aliran data menuju dan dari sistem diketahui menganalisis dari wawancara dengan user dan sebagai hasil analisis dokumen. Diagram konteks dimulai dengan penggambaran terminator, aliran data, aliran control penyimpanan, dan proses tunggal yang menunjukkan keseluruhan sistem. Bagian termudah adalah menetapkan proses (yang hanya terdiri dari satu lingkaran) dan diberi nama yang mewakili sistem. Nama dalam hal ini dapat menjelaskan proses atau pekerjaan atau dalam kasus ekstrim berupa nama perusahaan yang dalam hal ini mewakili proses yang dilakukan keseluruhan organisasi. Terminator ditunjukkan dalam bentuk persegi panjang dan berkomunikasi langsung dengan sistem melalui aliran data atau penyimpanan eksternal antar terminator tidak diperbolehkan komunikasi secara langsung. Pada kenyataannya hubungan antar terminator dilakukan tetapi secara definitif karena terminator adalah bagian dari lingkungan, maka tidak relevan jika di bahas dalam diagram konteks.[8]

\section{METODOLOGI PENELITIAN}

Metodologi penelitian merupakan suatu teknik atau untuk mengumpulkan data yang nantinya akan dipelajari dan akhirnya sebagai bahan untuk di analisa.[3]

\section{A. Metode Pengumpulan Data}

1) Observasi

Melakukan observasi atau peninjauan tempat sebelum pelaksanaan kegiatan pengumpulan data dengan mengadakan pengenalan terhadap objekobjek penelitian, aktivitas kerja dan bahan kajian. Observasi dalam penelitian ini dilaksanakan di SD Calisa Tanjung Uban yang beralamatkan di Jl Bhakti Praja, Pasar Baru Tanjunguban, Kepulauan Riau, Indonesia. Observasi dilakukan dengan mengamati proses PPSB di SD Calisa Tanjung Uban yang selama ini berjalan.

2) Wawancara

Melakukan wawancara secara langsung dengan pihak-pihak yang terlibat dalam sistem. Wawancara yang dilakukan bertujuan untuk mengetahui permasalahan - permasalahan atau kendala - kendala yang dihadapi pada saat ini. Wawancara yang dilakukan pada penelitian skripsi ini dengan mengambil responden Kepala Sekolah dan Panitia Penerimaan Siswa Baru (PPSB) SD Calisa Tanjung Uban.

3) Studi Pustaka

Studi pustaka adalah metode pengumpulan data melalui pengumpulan data secara tidak langsung dengan melakukan studi kepustakaan, yaitu dengan mengumpulkan data-data dan teoriteori yang berhubungan dengan penelitian ini.

\section{B. Metode Pengembangan Perangkat Lunak}

Metode pengembangan perangkat lunak yang digunakan dalam pengembangan aplikasi ini menggunakan model Spiral yang memiliki sifat interaktif yaitu dengan sifat kemungkinan perangkat lunak dikembangkan versinya secara bertahap untuk menghasilkan perangkat lunak yang lengkap dan terkontrol.Dalam Spiral Model, pengembangan tidak dilakukan langsung secara penuh dari kebutuhan aplikasi yang dikembangkan, namun aplikasi akan dikembangkan secara bertahap dengan menggunakan prototype. Hal ini ditujukan agar fungsi-fungsi yang terdapat pada sistem dapat lebih terfokus, sehingga mengoptimalkan proses pengujian pada sistem yang dikembangkan.[4] 


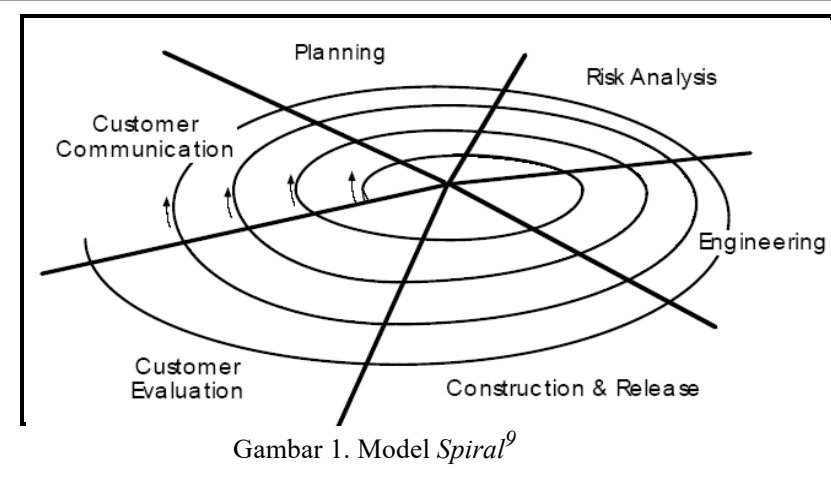

Paradigma dari tahapan model Spiral adalah sebagai berikut:

1. Komunikasi Pelanggan (Customer Communication), komunikasi dilakukan untuk mengetahui keinginan si pelanggan.

2. Perencanaan (Planning), pada tahap ini dilakukan pendefinisian sumber daya, waktu yang dibutuhkan, dan informasi lainnya terkait pembuatan perangkat lunak.

3. Analisis resiko (Risk Analysis), menganalisis resiko manajemen dan resiko teknis saat pembuatan perangkat lunak.

4. Perekayasaan (Engineering), membangun satu atau lebih representasi dari aplikasi.

5. Konstruksi dan peluncuran (Construction \& Release), pada proses ini perangkat lunak dan akan memberikan pelayanan pada pelanggan.

6. Evaluasi (Customer Evaluation), pelanggan, pelanggan akan memberikan pendapat tentang perangkat lunak yang telah dibuat. Apakah perangkat lunak akan dikembangkan kembali atau tidak.

\section{HASIL DAN PEMBAHASAN}

\section{A. Analisa Sistem}

Analisis sistem adalah teknik pemecahan masalah yang menguraikan bagian-bagian komponen dengan mempelajasi seberapa bagus bagian - bagian komponen tersebut bekerja dan berinteraksi untuk mencapai tujuan mereka.

1) Prosedur penerimaan siswa baru yang berjalan

- Calon Siswa mengambil formulir pendaftaran pada Panitia Penerimaan Siswa Baru (PPSB).

- Calon Siswa menyerahkan formulir pendaftaran yang telah diisi lengkap beserta kelengkapan persyaratan yang telah ditentukan ke Panitia Penerimaan Siswa Baru (PPSB).

- Lalu Panitia Penerimaan Siswa Baru (PPSB) akan memeriksa formulir pendaftaran serta kelengkapannya, apabila telah sesuai PPSB akan mencatatnya sebagai data calon siswa baru dan apabila kelengkapan persyaratan tidak lengkap PPSB akan mengembalikan kembali kepada calon siswa.

- Setelah itu PPSB akan menyeleksi calon siswa lalu membuat Surat Pemberitahuan Kelulusan yang harus ditandatangani kepala sekolah untuk diberikan kepada calon siswa.

- Kemudian calon siswa yang sudah mempunyai surat pemberitahuan kelulusan dengan keterangan diterima, akan melakukan registrasi dengan membawa surat keterangan diterima dan mengisi formulir registrasi untuk dijadikan dan siswa baru.

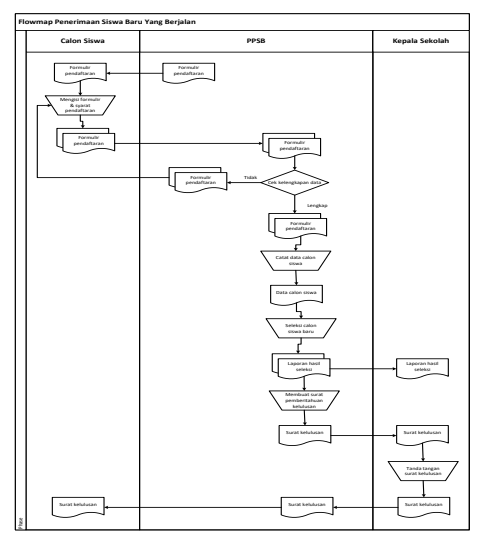

Gambar 2. Flowmap prosedur penerimaan siswa baru yang berjalan

\section{B. Analisa Kebutuhan Sistem}

1) Analisa SWOT sistem yang berjalan

a. Kekuatan (Strength)

- Proses pendaftaran pada SD Calisa Tanjunguban masih dilakukan secara gratis atau tanpa biaya pendaftaran.

b. Kelemahan ( Weakness )

- Pengelolaan data calon siswa mulai dari pencatatan awal pendaftaran, seleksi dokumen, data masih manual dan mudah terjadi kesalahan.

- Pencarian data-data calon siswa membutuhkan waktu yang cukup lama dikarenakan masih berupa arsip.

- Pembuatan laporan data calon siswa dan perbaikan data bila ada perubahan mengalami kesulitan karena harus mencari satu persatu. 
- Sistem lama kurang ekonomis karena penggunaan kertas, tinta dan alat tulis yang berlipat ganda dalam pencatatan data dan pembuatan laporan mengakibatkan terjadinya pemborosan biaya.

c. Peluang ( Opportunity)

- Dapat dibuatkan aplikasi pencatatan data calon siswa mulai dari pencatatan awal pendaftaran hingga proses seleksi siswa baru secara otomatis.

- Dapat dibuatkan aplikasi penerimaan siswa baru berbasis web dengan mengunakan fitur sms gateway sengingga penyampaian informasi penerimaan siswa baru dapat di distribusikan dengan cepat.

- Dapat dibuatkan aplikasi pendaftaran secara online sehingga dapat meminimalisir terjadi kesalahan penginputan data oleh petugas PPSB karena data langsung di isi oleh calon siswa dan juga meminimalisir terjadinya kehilangan data dibadingkan dengan menggunakan kertas fomulir pendaftaran.

- Dapat dibuatkan aplikasi yang dapat membuat laporan calon siswa baru, laporan hasil seleksi calon siswa baru dan pembuatan surat kelulusan siswa baru.

d. Ancaman (Threat)

- Dengan pengunaan kertas untuk surat kelulusan siswa baru maka pendistribusian akan membutuhkan waktu yang lama karena masih dilakukan secara manual.

- Resiko kerusakan dan kehilangan data juga bisa terjadi kerena masih menggunakan kertas manual.

\section{Perancangan Sistem}

Perancangan sistem dapat didefinisikan sebagai penggambaran, perencanaan dan pembuatan sketsa atau pengaturan dari beberapa elemen yang terpisah ke dalam satu kesatuan yang utuh dan berfungsi.[10]

1) Prosedur penerimaan siswa baru yang diusulkan

- Calon siswa baru mendaftar dengan cara menginputkan data siswa baru ke sistem.

- Panitia Penerimaan Siswa Baru kemudian mencetak laporan hasil PSB. Laporan hasil PSB nantinya akan diberikan ke kepala sekolah.

- Sistem kemudian mengirim SMS notifikasi ke siswa baru yang diterima ke calon siswa baru, yang didalamnya terdapat nomor untuk pendaftaran ulang.

- Calon siswa baru kemudian melakukan proses pendaftaran ulang dengan nomor daftar ulang ke sistem PSB.
- Panitia Penerimaan Siswa Baru kemudian mencetak laporan hasil daftar ulang, yang nantinya akan diberikan ke kepala sekolah.

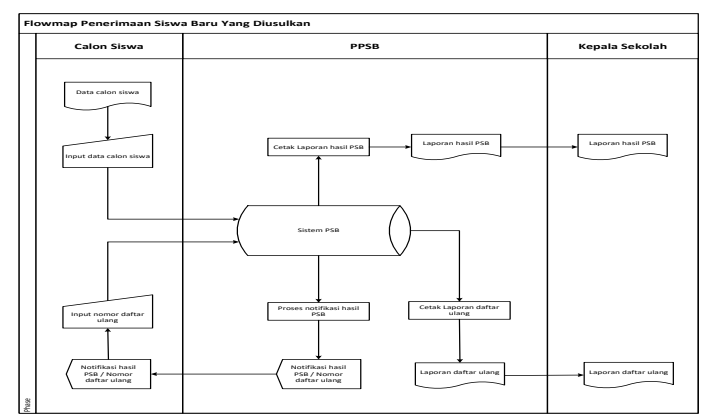

Gambar 3. Flowmap prosedur penerimaan siswa baru yang diusulkan

\section{2) Diagram konteks}

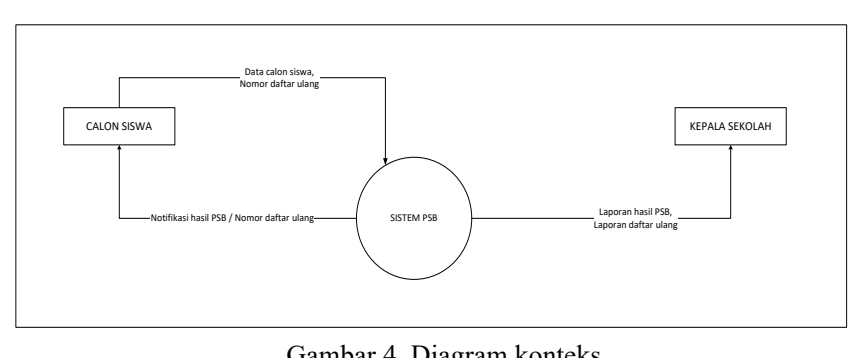

Gambar 4. Diagram konteks

3) Data flow diagram

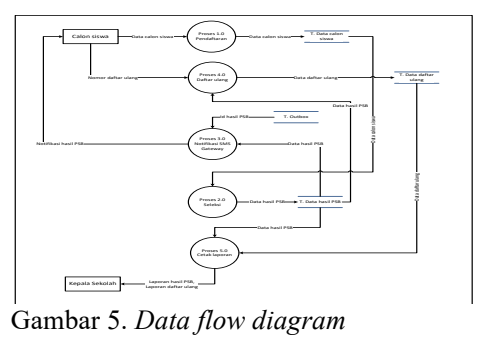

Gambar 5. Data flow diagram

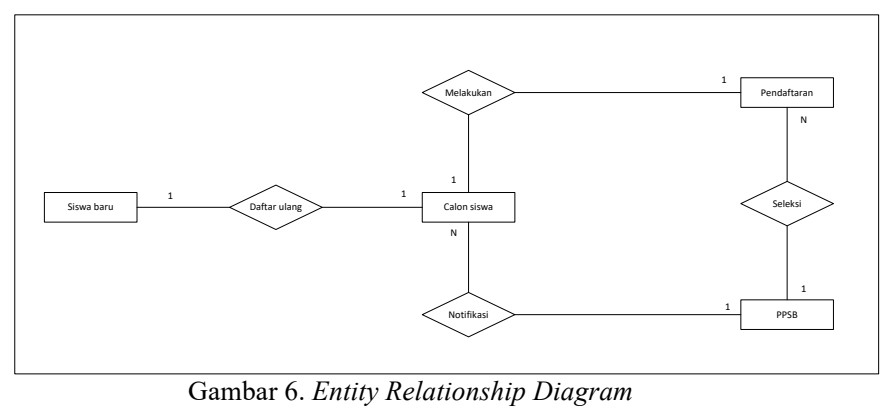

4) Struktur program 


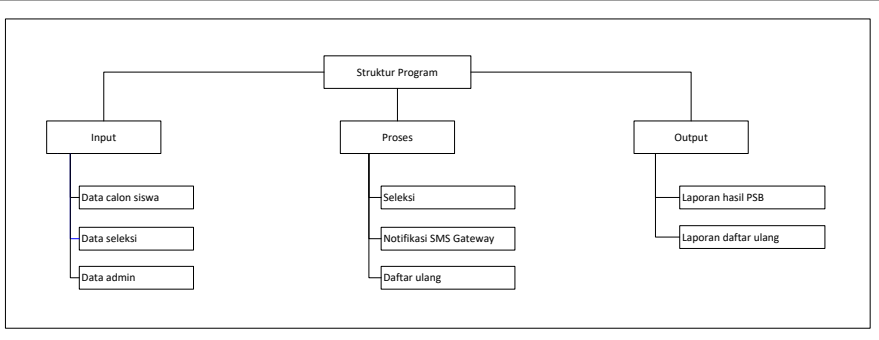

Gambar 7. Struktur program

\section{5) Struktur menu}

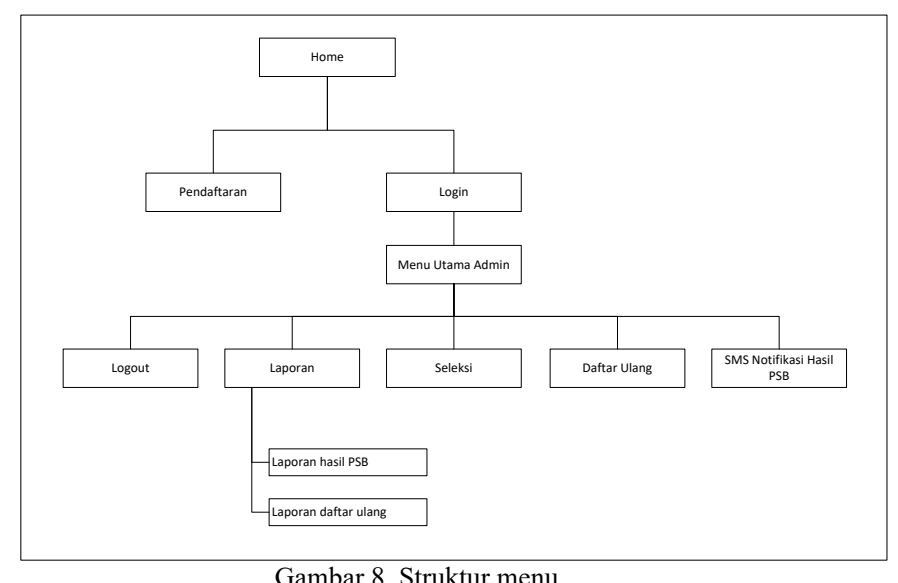

Gambar 8. Struktur menu

\section{Implementasi}

Tahap implementasi sistem ini merupakan tahap meletakkan perancangan sistem kedalam bentuk bahasa pemrograman, kemudian diimplementasikan ke dalam instansi atau lembaga tersebut.[11]

1) Implementasi pemrograman

Rancangan sistem ini dikembangkan dan diimplementasikan dengan bahasa pemrograman PHP (Hypertext Preprocessor) menggunakan Sublime Text-3 sebagai Web editor yang digunakan untuk mengetikan kode - kode program PHP, HTML, CSS dan Javasript.

2) Implementasi database

Implementasi pembangunan data base dilakukan menggunakan localhost atau komputer lokal, menggunakan MySQL sebagai program editornya.

\section{E. Pengujian}

Pengujian sistem adalah prosedur yang dilakukan untuk menyelesaikan rancangan sistem yang telah disetujui, menguji sistem, menginstal serta memulai penggunaan sistem baru atau sistem yang telah diperbaiki[12]. Pengujian sistem bertujuan untuk melihat apakah sistem yang telah dibuat sudah sesuai dengan tujuan awal pembuatan dan layak untuk dipergunakan. Pengujian sistem termasuk juga pengujian program secara menyeluruh[5]. Pada pengujian program ini menggunakan jenis pengujian secara black box testing.
Black Box Testing sendiri merupakan pengujian yang dilakukan hanya mengamati hasil eksekusi melalui data uji dan memeriksa fungsional dari perangkat lunak. Pengujian black box ini menitik beratkan pada fungsi system [6].

Black box testing adalah pengujian yang dilakukan dengan hanya mengamati hasil eksekusi atau interface melalui data uji dan memeriksa fungsional dari perangkat lunak. Jika dianalogikan, maka pengujian black box testing hanya bisa mengevaluasi dari tampilan luarnya (interface) saja, fungsionalitasnya saja tanpa mengetahui apa sesungguhnya yang terjadi dalam proses detailnya. Ada beberapa jenis pengujian perangkat lunak, antara lain :

a) Pengujian white box adalah pengujian yang didasarkan pada pengecekan terhadap detail perancangan, menggunakan struktur kontrol dari desain program secara prosedural untuk membagi pengujian ke dalam beberapa kasus pengujian. Secara sekilas dapat diambil kesimpulan white box testing merupakan petunjuk untuk mendapatkan program yang benar secara $100 \%$,

b) Black-Box Testing merupakan pengujian yang berfokus pada spesifikasi fungsional dari perangkat lunak, tester dapat mendefinisikan kumpulan kondisi input dan melakukan pengetesan pada spesifikasi fungsional program [7].

\section{KESIMPULAN DAN SARAN}

Berdasarkan penelitian yang dilakukan penulis dalam mengembangkan sistem penerimaan siswa baru di SD Calisa Tanjung Uban, maka penulis mengambil kesimpulan :

1. Sistem penerimaan siswa di SD Calisa Tanjung Uban telah dikembangkan menggunakan PHP dan MySQL dilengkapi dengan SMS Gateway serta mempunyai fitur - fitur untuk mengolah data pendaftaran calon siswa baru, data seleksi, data daftar ulang, SMS Gateway, data hasil PSB dan data daftar ulang.

2. Dengan menggunakan sistem informasi penerimaan siswa baru berbasis Web, maka penggunaan kertas sebagai formulir pendaftaran siswa baru tidak lagi digunakan sehingga resiko kehilangan data bisa dihindari.

3. Dengan adanya fitur SMS Gateway pada sistem informasi penerimaan siswa baru berbasis Web, maka penyampaian hasil PSB dapat didistribusikan secara cepat dan akurat ke calon siswa baru.

\section{REFERENSI}

[1] N. L. P. Merawati, A. Bachtiar, and Apriani, "Penerapan Sms Gateway Pada Aplikasi Pendaftaran," vol. 18, no. 1, pp. 159170,2018

[2] T. Hidayat, M. Muttaqin, and D. Djamaludin, "Sistem 
Informasi Penerimaan Peserta Didik Baru Online Berbasis Website di Yayasan Pendidikan Arya Jaya Sentika,"

Komputika J. Sist. Komput., vol. 9, no. 1, pp. 7-14, 2020, doi: 10.34010/komputika.v9i1.2750.

[3] M. Mulyadi, "Riset Desain Dalam Metodologi Penelitian," $J$. Stud. Komun. dan Media, vol. 16, no. 1, p. 71, 2013, doi: 10.31445/jskm.2012.160106.

[4] H. Kusmiati and M. Ansori, "Aplikasi Pemasangan Layanan Reguler Smart PT.PLN (Persero) menggunakan Spiral Model," JSM STMIK Mikroskil, vol. 16, no. 1, pp. 61-71, 2015.

[5] U. Hanifah, R. Alit, and S. Sugiarto, "Penggunaan Metode Black Box Pada Pengujian Sistem Informasi Surat Keluar Masuk," SCAN - J. Teknol. Inf. dan Komun., vol. 11, no. 2, pp. 33-40, 2016, [Online]. Available:

http://ejournal.upnjatim.ac.id/index.php/scan/article/view/643.

[6] T. Hidayat and M. Muttaqin, "Pengujian Sistem Informasi Pendaftaran dan Pembayaran Wisuda Online menggunakan Black Box Testing dengan Metode Equivalence Partitioning dan Boundary Value Analysis," J. Tek. Inform. UNIS JUTIS, vol. 6, no. 1, pp. 2252-5351, 2018, [Online]. Available: www.ccssenet.org/cis.

[7] Syaban, Rizki Maulana Syaban, H.Bunyamin. "Pengembangan sistem informasi pengelolaan surat masuk dan keluar berbasis web di dinas sosial tenaga kerja dan transmigrasi kabupaten garut menggunakan framework php". 2015.

[8] Andi, Pemrograman PHP dan My SQL Untuk Pemula, MADCOMS, Yogyakarta, 2016.

[9] Feri Hari Utami, Rekayasa Perangkat Lunak, Penerbit ANDI, Yogyakarta, 2015.

[10] Muhammad Muslihudin dan Oktafianto, Analisis dan Perancangan Sistem Informasi Menguunakan Model Terstruktur dan UML, Penerbit ANDI, Yogyakarta, 2016.

[11] Wahana Komputer, Mudah Membuat Aplikasi SMS Gateway dengan Codeigniter, Mediakom, Yogyakarta, 2014.

[12] Bayu Hendradjaya, Konsep Dasar Pengujian Perangkat Lunak, Penerbit ITB, 2017, Bandung. 